\title{
Assessments of ecological health using soil algae diversity in Jargalant-Tain pass, Bogdkhan mountain
}

Bukhchuluun Tsegmid

Laboratory of Plant Systematics and Phylogeny, Botanic Garden and Research Institute Mongolian Academy of Sciences, Ulaanbaatar, Mongolia

Abstract: This study is the first of its kind in Mongolia to make an ecological health assessment of birch forest, based on the composition of soil algae species. The Chlorophyta consisted of 54.5 percent of the total algae species. In Jargalant-Tain pass, Bogdkhan Mountain, the ground of the birch forest is drying up. Deterioration of forest soil ecology and the onset of aridity indicate the process of deforestation. Therefore, reforestation is urgently needed.

Keywords: soil; algae; species; ecological health;

\section{INTRODUCTION}

One celled and filamentous algae in the soil are microscopic and are not visible to the naked eye. Still, they are located on the soil surface and in the middle of the ground, forming a biocoenosis of other microorganisms [1].

Soil algae have a significant impact on soil ecological processes in absorbing moisture and nutrients, producing organic matter with the help of sunlight and nutrition of other microorganisms, it is involved in the process of soil formation and nutrient fortification, it maintains and stabilizes soil moisture, protects against water loss, protects soil from erosion, and is involved in biogeochemical soil cycle. [2].
Novichkova-Ivanova first studied soil algae in Mongolia in 1977 and identified 67 algae species in Zuungar Gobi and Trans-Altai Gobi [3].

The detection and evaluation of algae species in the soil allow us to assess the essential characteristics, the usage, and the protection of vegetation biogeocenosis [1].

A soil alga is considered healthy if it contains about 20 percent of the soil's total microorganisms [3].

This study aimed to assess the ecological health of birch forest soils using each species habitat and determine the composition of algae species in the soil of Jargalant-Tain pass in Bogdkhan Mountain.

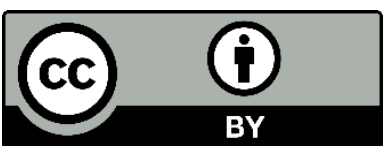

The Author(s). 2021 Open access This article is distributed under the terms of the Creative Commons Attribution 4.0 International License (https://creativecommons.org/licenses/by/4.0/), which permits unrestricted use, distribution, and reproduction in any medium, provided you give appropriate credit to the original author(s) and the source, provide a link to the Creative Commons license, and indicate if changes were made. 


\section{MATERIALS AND METHODS}

The general methodology of algae collection was used in the study in a specific research area. It is considered that no tools are needed to study the elements of large pools.

Soil algae, like other algae, are rarely agglomerated. Therefore, an algae sample is taken from the soil and grown in a nutrient medium to prepare a culture to detect algae species. For this purpose, a $2 \mathrm{~cm}$ deep, $5 \mathrm{~cm}$ long, and $50 \mathrm{~cm} 3$ wide piece was taken from the topsoil, stored in a sealed bag, and addressed to the laboratory. The soil vegetation communities, where the samples were collected, were recorded to identify plant species and reflective cover per $\mathrm{m} 2$. A total of 6 samples of moist moss (Table 1) were collected from the soil surface and the base soil to a depth of $2 \mathrm{~cm}$.

Table 1. Samples

\begin{tabular}{|c|c|c|c|c|}
\hline & Samples & Location & $\begin{array}{l}\text { Vegetation } \\
\text { cover \% }\end{array}$ & Vegetation community \\
\hline 1 & Soil & \multirow{2}{*}{$\begin{array}{l}\mathrm{N} 47^{\circ} 47^{\prime} 46.9^{\prime \prime} \\
\mathrm{E} 106^{\circ} 48^{\prime} 19.2^{\prime \prime} \\
1538 \mathrm{M}\end{array}$} & \multirow{2}{*}{$\begin{array}{l}\text { Litter-15 } \\
\text { Bare-5 } \\
\text { Rock-0 } \\
\text { Canopy-80 }\end{array}$} & \multirow[t]{2}{*}{ Forb-sedge shrub } \\
\hline 2 & Moist moss & & & \\
\hline 3 & Soil & \multirow{2}{*}{$\begin{array}{l}\mathrm{N} 47^{\circ} 47^{\prime} 43.0^{\prime \prime} \\
\text { E } 106^{\circ} 48^{\prime} 9.8^{\prime \prime} \\
1566 \mathrm{M}\end{array}$} & \multirow{2}{*}{$\begin{array}{l}\text { Litter-20 } \\
\text { Bare-5 } \\
\text { Rock-0 } \\
\text { Canopy-75 }\end{array}$} & \multirow[t]{2}{*}{ Forb-shrub } \\
\hline 4 & Moist moss & & & \\
\hline 5 & Soil & \multirow{2}{*}{$\begin{array}{l}\text { N } 47^{\circ} 47^{\prime} 36.9^{\prime \prime} \\
\text { E106 } 48^{\prime} 15.4^{\prime \prime} \\
1615 \mathrm{M}\end{array}$} & \multirow{2}{*}{$\begin{array}{l}\text { Litter-15 } \\
\text { Bare-5 } \\
\text { Rock-3 } \\
\text { Canopy-77 }\end{array}$} & \multirow[t]{2}{*}{ Birch forest with mosses } \\
\hline 6 & Moist moss & & & \\
\hline
\end{tabular}

The algae sample material was to the laboratory, the soil was placed in a clean glass container, 30 per cent saline solution was added to a 80-100 per cent moisture, the container was covered with a clean glass and kept at a plus room temperature. A few drops of the preparation was taken using filter paper and placed under a microscope to determine algae species on a scale of 1 to 6 . Algae growth was decided at the species level by injecting $10 \mathrm{ml}$ of filtrate into the prepared medium of Bold and $60 \mathrm{ml}$ of each match medium into a $100 \mathrm{ml}$ flask [4].

The size of the algae is vital in determining its external properties, as it is impossible to determine such properties it without any measurement. Therefore, an alley with a measuring line was used to measure the algae under a microscope. In order to determine the eyepiece micrometers partition size, a measuring eyepiece was placed in the microscope tube and the object micrometer was set on the shelf. The object micrometer is $1 \mathrm{~mm}$ long and divided into 100 sections, each 0.01 $\mathrm{mm}$. In order to find out if the line of the measuring tube is equal to the algae at a given magnification, it is necessary to determine the correspondence between the eyepiece line and the line of the object micrometer. For example, if ten lines on an eyepiece micrometer correspond to 5 lines on an object micrometer (i.e. $0.05 \mathrm{~mm}$ ), then one line on the eyepiece measuring line is $0.05 / 10=0.005 \mathrm{~mm}=5 \mu \mathrm{m}$. Various chemical reagents are used to identify algae, such as $\mathrm{KOH}$, Lugol solution, chlorinezinc-iodine, gentianviolite, and clump. Algae cells are stained with 5 percent $\mathrm{KOH}$. Lugol solution is used to detect algae sticks, particles, and starch granules, which is prepared by adding $1 \mathrm{~g}$ of iodine and $2 \mathrm{~g}$ of $\mathrm{KJ}$ to $300 \mathrm{~cm}^{3}$ of water. The cellulose (fiber) coating turns pink when chlorine-zinc-iodine solution stains algae cells. To prepare the solution, heat 8.5 $\mathrm{cm}^{3}$ of water, dissolve $20 \mathrm{~g}$ of $\mathrm{ZnCe} 2$, let it stand, and add $3 \mathrm{~g}$ of $\mathrm{KJ}$ and $1.5 \mathrm{~g}$ of $\mathrm{J}$ to $60 \mathrm{~cm}^{3}$ of water. Store the solution in a dark glass 
u1093, protected from light. Gentsioviolite solution is used to stain algae nuclei, stalks, saliva and to detect chromatophores' shape. Diluted solutions are also widely used to clarify algae mucilaginous.

\section{RESULTS AND DISCUSSION}

A total of 11 algae species were recorded in the soil of the birch forest. There are one species of Cyanophyta, three species of ochrophyta, six species of green algae (Chlorophyta), and one species of charophyte. Following species were identified:

\section{Botrydiopsis arhiza Borzm 1895: 70.}

Ulaanbaatar: Khan-uul district, Bogdkhan mountain, Tain pass (N47 $47^{\prime} 46.9^{\prime \prime}$, E10648'19.2"; 1538m) Dark brown soil with forb-shrubs of mountain steppe. №UBA-5930. 28.08.2020. Bukhchuluun Ts.

2. Bracteacoccus minor (Schmidle ex Chodat) Petrov6 1931:221.

Ulaanbaatar: Khan-uul district, Bogdkhan mountain, Tain pass (N47 $47^{\prime} 46.9^{\prime \prime}$, E106 ${ }^{\circ} 8^{\prime} 19.2^{\prime \prime} ; 1538 m$ ) Dark brown soil in mountain steppe forb-sedge-shrub communities. №UBA-5930 28.08.2020. Bukhchuluun Ts.

3. Chlamydomonas elliptica Korshikov in Pascher 1927: 265.

Ulaanbaatar: Khan-uul district, Bogdkhan mountain, Tain pass (N47 $47^{\prime} 36.9^{\prime \prime}$, E106 48'15.4"; 1615m) Mountain light moss birch forest dark soil. №UBA-5934 28.08.2020. Bukhchuluun Ts.

4. Chlorococcum infusionum (Schrank) Meneghini 1842: 27.

Ulaanbaatar: Khan-uul district, Bogdkhan mountain, Tain pass (N 47 47'43.0", E 106 48'9.8" 1566m) Dark brown soil in mountain steppe forb-sedge-shrub communities. №UBA-5932. 28.08.2020. Bukhchuluun Ts.

5. Klebsormidium flaccidum (Kьtzing) P.C.Silva, K.R.Mattox \& W.H.Blackwell 1972: 643.

Ulaanbaatar: Khan-uul district, Bogdkhan mountain, Tain pass (N47 $47^{\prime} 46.9^{\prime \prime}$,
The immersion oil droplet base was determined at 1000 magnification under a microscope $[5,6,7,8]$ to the species level, assessing birch forest ecological health using the life form of soil algae [3].

E10648'19.2"; 1538m) Moss soils with forbshrub in mountain steppe. №UBA-5931. 28.08.2020. Bukhchuluun Ts.

6. Leptolyngbya foveolarum (Gomont) Anagnostidis \& Komбrek 1988: 391.

Ulaanbaatar: Khan-uul district, Bogdkhan mountain, Tain pass ( $47^{\circ} 47^{\prime} 43.0^{\prime \prime}$, E 106 48'9.8" 1566m) Moss soils with forbshrub in mountain steppe c. №UBA-5933. 28.08.2020. Bukhchuluun Ts.

7. Leptosira polychloris Reisigl 1964: 481.

Ulaanbaatar: Khan-uul district, Bogdkhan mountain, Tain pass (N47 $47^{\prime} 46.9^{\prime \prime}$, E106 $48^{\prime} 19.2^{\prime \prime} ; 1538 \mathrm{~m}$ ) Dark brown soil in mountain steppe forb-sedge-shrub communities. №UBA-5930. 28.08.2020. Bukhchuluun Ts.

8. Microspora tumidula Hazen 1902: 177.

Ulaanbaatar: Khan-uul district, Bogdkhan mountain, Tain pass (N47 $47^{\prime} 46.9^{\prime \prime}$, E106 ${ }^{\circ} 8^{\prime} 19.2^{\prime \prime} ; 1538 m$ ) Dark brown soil in mountain steppe forb-sedge-shrub communities. №UBA-5930. 28.08.2020. Bukhchuluun Ts.

9. Pleurochloris commutata Pascher 1925: 46.

Ulaanbaatar: Khan-uul district, Bogdkhan mountain, Tain pass (N 47 47'36.9", E106 48'15.4" 1615m) Dark brown soil with light brown moss in birch forest. №UBA-5935. 28.08.2020. Bukhchuluun Ts.

10. Sphaerosorus sp

11. Stichococcus bacillaris Nдgeli 1849: 76.

Ulaanbaatar: Khan-uul district, Bogdkhan mountain, Tain pass (N 47 47'36.9", E10648'15.4" 1615m) Dark brown soil with light brown moss birch forest. №UBA-5935. 28.08.2020. Bukhchuluun Ts.

The following Table 2 lists the species composition in detail for each taxon. 


\begin{tabular}{|l|l|l|l|l|}
\hline \multicolumn{1}{|c|}{ Phylum } & \multicolumn{1}{|c|}{ Class } & \multicolumn{1}{c|}{ Order } & \multicolumn{1}{c|}{ Family } \\
\hline Cyanophyta & Cyanophyceae & Synechococcales & Leptolyngbyaceae & Leptolyngbya foveolarum \\
\hline Ochrophyta & Xanthophyceae & Mischococcales & Botrydiopsidaceae & Botrydiopsis arhiza \\
\hline Ochrophyta & Xanthophyceae & Mischococcales & Pleurochloridaceae & Pleurochloris commutata \\
\hline Ochrophyta & Xanthophyceae & Mischococcales & Botryochloridaceae & Sphaerosorus sp \\
\hline Chlorophyta & Chlorophyceae & Chlamydomonadales & Chlorococcaceae & Chlorococcum infusionum \\
\hline Chlorophyta & Chlorophyceae & Chlamydomonadales & Chlamydomonadaceae & Chlamydomonas elliptica \\
\hline Chlorophyta & Chlorophyceae & Sphaeropleales & Microsporaceae & Microspora tumidula \\
\hline Chlorophyta & Chlorophyceae & Sphaeropleales & Bracteacoccaceae & Bractaecoccus minor \\
\hline Chlorophyta & Trebouxiophyceae & Prasiolales & Stichococcaceae & Stichococcus bacillaris \\
\hline Chlorophyta & Trebouxiophyceae & $\begin{array}{l}\text { Trebouxiophyceae ordo } \\
\text { incertae sedis }\end{array}$ & $\begin{array}{l}\text { Trebouxiophyceae } \\
\text { incertae sedis }\end{array}$ & Leptosira polychloris \\
\hline Charophyta & Klebsormidiophyceae & Klebsormidiales & Klebsormidiaceae & Klebsormidium flaccidum \\
\hline
\end{tabular}

The algae life form is also listed.

Table 3. Life form of soil algae

\begin{tabular}{|l|l|l|}
\hline & $\begin{array}{l}\text { Algae life form } \\
\text { in the soil }\end{array}$ & \\
\hline 1 & $\mathrm{C}$ & Chlamydomonas elliptica \\
\hline 2 & $\mathrm{Ch}$ & $\begin{array}{l}\text { Botrydiopsis arhiza, Chlorococcum infusionum, Bractaecoccus minor, Leptosira } \\
\text { polychloris }\end{array}$ \\
\hline 3 & $\mathrm{H}$ & Microspora tumidula, Klebsormidium flaccidum \\
\hline 4 & $\mathrm{X}$ & Stichococcus bacillaris, Pleurochloris sp, Sphaerosorus sp \\
\hline 5 & $\mathrm{P}$ & Leptolyngbya foveolarum \\
\hline
\end{tabular}

The life forms are $\mathrm{p}-1, \mathrm{ch}-4, \mathrm{x}-3, \mathrm{c}-1$, and h-2. 36.3 per cent of the species are ch or singlecelled, colonies and soil-surface. 27 per cent are one-celled algae species that live in the middle of the soil. Some alga species are attached as a representation of algae life. Microscope magnification is at 1200 .
Leptolyngbya foveolarum

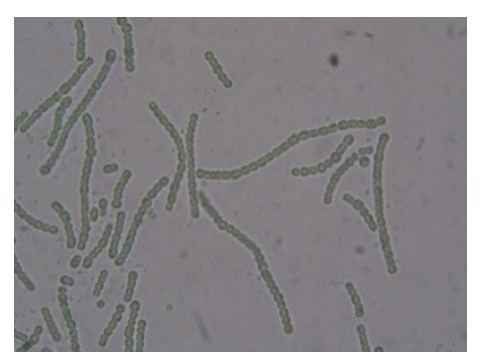

Leptosira polychloris

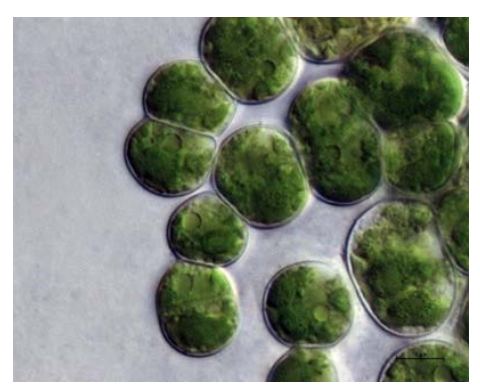

Chlorococcum infusionum

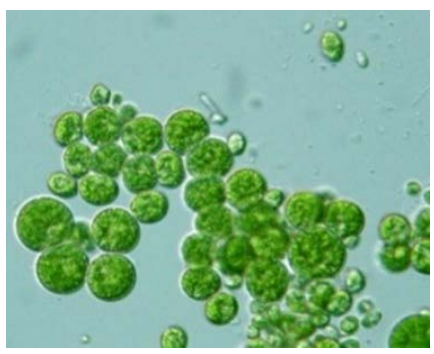

Stichococcus bacillaris

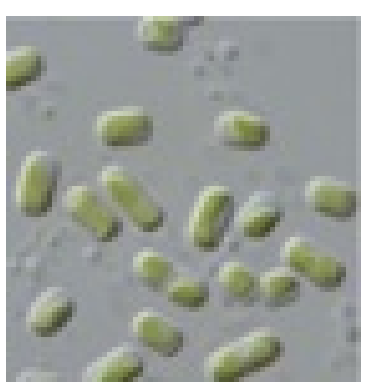

Klebsormidium flaccidum

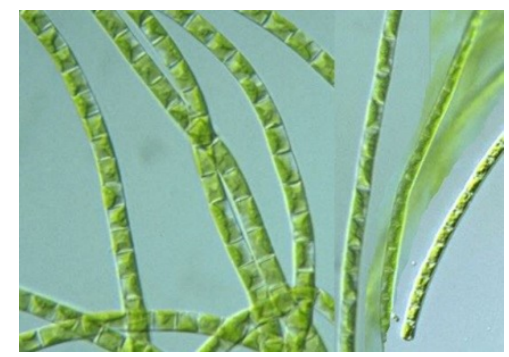

Chlamydomonas elliptica

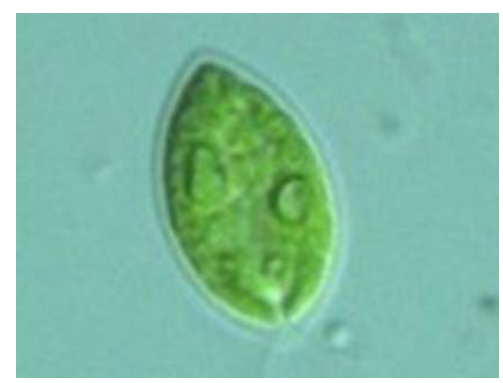

Figure 1. Dominant species image

Surface algae three species occur at an altitude of $1538 \mathrm{~m}$ and one species at an altitude of $1566 \mathrm{~m}$, while species living in the middle part of the soil occur at $1615 \mathrm{~m}$. Some results 
are illustrated in Figure 2. Green algae species are more common at low altitudes, while ochrophytes are predominant at the highest elevation of our study area. In $1566 \mathrm{~m}$, some species, belonging to Cyanophyta, occurred in forb-shrub vegetation community. The $\mathrm{C}$ and $\mathrm{X}$ lifeforms demand moisture and tolerate shadow. $\mathrm{P}$ group is indicative of xerophyte. At $1566 \mathrm{~m}$, two species of two groups have been recorded; the moisture and dryness indicators coincide. Here the vegetation cover was canopy 75. But at 1538 and 1615 meters, the canopy was 77-80. The above results indicate that the forest is drying up from the edge.

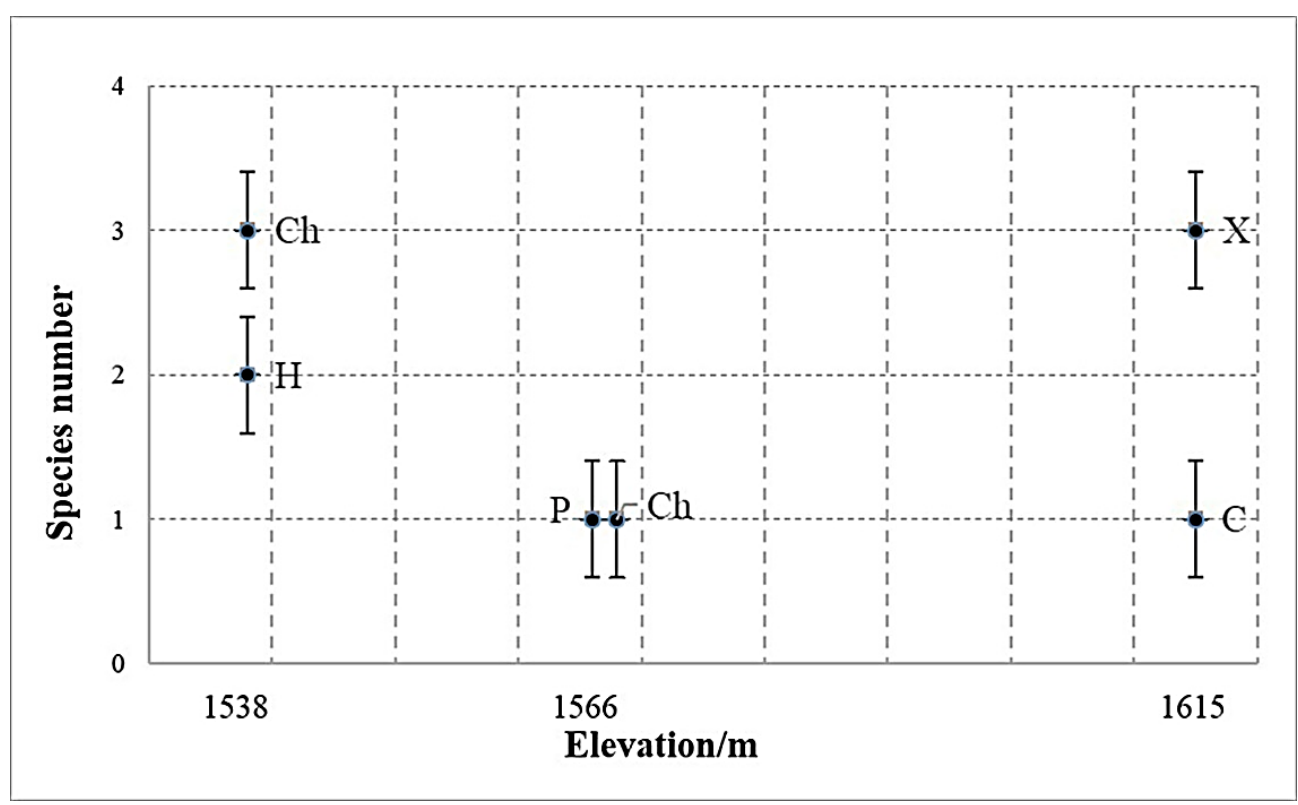

Figure 2. Relation between elevation and species number

Soil algae were first studied in the Gobidesert soil, and 67 species were recorded, of which 58 were blue-green and green algae [9]. Although our study differs from gobi soil algae, the proportion of the dominant species was the same. According to [3], the most abundant spruce and pine forests species are in Moscow and Novosibirsk. Eighty-five species in birch forests have been recorded in the Moscow region, 42 green algae. Fifteen species were recorded from birch forests in the Novosibirsk region and the 11 species in our results. The above results are diverse by the richness of species algae in the same birch forest depending on the soil classification. In other words, soil moisture and forest density affect species richness. This result can indicate soil health.

Green algae predominate cyanobacteriaalgal cenoses of the investigated soils [10]. The result of our study shows that Chlorophyta consisted of 54.5 per cent of the total algae species. Green algae or Chlorophyta is dominant in the soil algae community from the above study. This issue is confirmed in our birch forest.
The degradation of land ecosystems and their underlying basis - the soil - has a global nature. Soil algae constitute an active autotrophic part of the microbiota to the importance of algae in the restoration of damaged soils. The soil microorganisms ensure sustainable existence of the ecosystem [11]. Soil algae are a natural soil-protecting biological factor and soil naturalization to restore damaged areas [12]. So the soil algae were cultivated in Acer plantation. The herbicide treatment negatively impacted the microalgal soil community. This study confirmed that structural stability of topsoil in temperate croplands can be improved by using indigenous soil algae, and cyanobacteria on an aggregate affected topsoil stability in cereal cropping systems [13]. It is necessary to conduct research in cropland areas in our country and use it in agriculture to protect the topsoil.

This study shows that study of soil algae should be improved in our country. On the other hand, we can use soil algae culture to decrease soil erosion. 


\section{CONCLUSIONS}

The species composition of the algae is much poorer than that of the algae communities of the Siberian birch forest. Most of them remain dormant when the soil moisture is insufficient and only begin to grow when there is sufficient moisture, indicating that the forest is drying up. There is a need to properly use and rehabilitate forests and protect them from

\section{REFERENCES}

1. Domracheva L. I., Zykova Y. N., Kovina A. L., Trefilova L. V. Soil algae: Study guide. - Kirov: Vyatka State Agricultural Academy, 2017. - 86 p. - ISBN 978-5-9909914-5-3.

2. Aleksakhina T.I., Shtina E.A. Soil algae of forest biogeocenoses. 1984. $148 \mathrm{pp}$.

3. Novichkova-Ivanova L. N. Soil algae of phytocenoses of the Sahara-Gobi desert region. L.: Nauka. 1980. p. 255.

4. Kuzyakhmetov G.G., Dubovik I.E. Methods for studying soil algae: a textbook. 2001.

5. Kursanov L. I. Keys to lower plants. Moscow: Soviet Science, 1953. - V. 1. Algae. - 395 s.

6. Kursanov L. I. Keys to lower plants. Moscow: Soviet Science, 1953. - V. 2. Algae. - p. 309.

7. Gollerbakh M. M., Shtina E. A. Soil algae. L.: Nauka, 1969. p. 228.

8. Gorlenko M. V. Lower Plants Course. M.: Higher school, 1981. p. 521.

9. Novichkova-Ivanova L. N. Soil and aerophilic algae of the Dzungarian and Trans-Altai Gobi deserts. Botany. J., 1977. V. 62, No. 12, pp. 1709-1719.

10. Korneikova M. V., Redkina V. V., Shalygina R. R. Algological and ecological degradation. It will help reduce global warming and reduce greenhouse gas emissions.

Acknowledgements: We would like to extend our thanks to Urgamal Magsar Ph.D. (head of Laboratory of Taxonomy and Phylogeny) and Enkhtuya Ochirbat, Ph.D., for supporting this research.

Mycological Characterization of Soils under Pine and Birch Forests in the Pasvik Reserve. Eurasian Soil Science., 2018. V. 51, pp. 211-220. https://doi.org/10.1134/S10642293180 20047

11. Sharipova M. Yu. Algae of rhizosphere of grassy plants Inzer River valley (Southern Ural). Izvestia of Samara Scientific Center of the Russian Academy of Sciences, 2012. Vol. 14 № 1(7), pp. 1880-1883.

12. Didur O. A., Kulbachko Yu. L., Maltsev Ye. I., Konovalenko T. V. Ecology of soil algae cenoses in Norway maple plantation in the recultivated territory of the Western Donbas (Ukraine). Ukrainian Journal of Ecology, 2018. Vol. 8(1), pp. 865872.

13. Crouzet O., Consentino L., Pétraud JP., Marrauld C., Aguer J-P., Bureau S., Le Bourvellec C., Touloumet L., and Bérard A. Soil Photosynthetic Microbial Communities Mediate Aggregate Stability: Influence of Cropping Systems and Herbicide Use in an Agricultural Soil. Front. Microbiol. 2019. 10:1319. doi: 10.3389/fmicb.2019.01319 